\title{
The Global Journey of the Bakhtiyārnāmah: New Evidence from the Lund University Archives
}

\author{
Jeff Eden
}

Harvard University

\begin{abstract}
The Bakhtiyarnamah is a truly global tale, found in multiple versions and in multiple languages throughout the Middle East, South Asia, Southeast Asia, the Caucasus, and beyond. Several copies of the tale exist in Chaghatay Turkic as well, but these copies have gone mostly unnoticed. This paper introduces two such copies held in the Lund University archives, both of which were made in East Turkistan (present-day Xinjiang, China), and argues for the benefit of studying cosmopolitan influences on East Turkistani literatures.
\end{abstract}

Keywords: East Turkistan, Chaghatay, Bakhtiyarnamah.

While the "global turn" in the discipline of history has involved a rededication among scholars to studying the interconnectedness and mutual influences of world civilizations long before the "modern" era, historical studies of literature and culture often remain fixated on articulating the "ethnic" and "national" dimensions of their subjects. It is therefore the perfect time to renew discussions of those tales and epics which are undeniably "global" in their dispersal, developing as 
part of a shared literary heritage across many cultures, over many centuries, and the Bakhtiyārnämah is a fine example of such a "global" tale. Appearing in various versions across the Middle East, the Caucasus, Central Asia, India, Malaysia and Indonesia, this frametale has also been well-known to scholars in the West for more than two centuries, and it has become a fixture in translations of the Thousand and One Nights. The story is best known in its Persian and Arabic versions, and much of our scholarship on the subject seeks to compare recensions in these two languages. There are also, in manuscript collections throughout the world, a number of copies of this tale in Chaghatay, and thus far these versions - with only one exception - have gone unnoticed. ${ }^{1}$ I have found, for example, two previously-unstudied Chagatay copies of the tale in the Lund University archives which contain an unusual divergence from all other known recensions in any language: namely, the relatively seamless insertion of an "extra" tale, famous in its own right, which is not found in any other version. I hope that the discovery of this novel recension will open up a new line of inquiry into the history of the much-discussed Bakhtiyār narrative. Moreover, because these Lund manuscripts were copied in Kashghar, we may now extend the geographic range of this widely-traveled tale to include East Turkistan (now the Xinjiang Uyghur Autonomous Region of China). Lastly, I hope that calling attention to this discovery will likewise call attention to the broader topic of the cosmopolitan nature of East Turkistani literature, a subject of great potential which has thus far been largely neglected in favor of "ethno-nationalist" interpretations of cultural history.

I will begin with an overview of the various versions and translations of the tale which are known to us. The earliest known copy of the Bakhtiyārnamah is a version in Arabic, dated to 390/1000, which has been published by Zabīh Allah Șafā (1347/1968), and there are several other Arabic versions of the narrative extant in manuscript collections as well. An Arabic text was the basis for Dom Chavis and

\footnotetext{
${ }^{1}$ The only Turkic version to have been the subject of formal study is a copy in Uyghur script held by the Bodleian library, which dates to 838/1435. This version has been described and partially translated into French by M.A. Jaubert (1827). An excerpt and partial translation of the same manuscript have been published in Arthur Lumley David's Grammar of the Turkish Language $(1832,169-78)$ and in Vambery's Uigurische Sprachmonumente und das Kudatku bilik (1870, 174-77).
} 
Jacques Cazotte's French translation of 1789, titled "Histoire de Bohetzad et de ses dix visirs" (240-259), in which the young protagonist is named Aladdin. In Sweden, an Arabic edition was published by Gustav Knös in 1807, followed several years later by his Latin and Swedish translations. This same Arabic text was the source for Basset's French translation, published in 1883. Another Arabic text was included in Habicht's famous Tausend und Eine Nacht, issued at Breslau between 1825-38 (the final three volumes were issued, after Habicht's death, in 1842-43). This "Breslau" text was translated by Gustav Weil (German, 1838-41), John Payne (English, 1882), Richard Burton (English, 1885), and Max Henning (German, 1895-97) for their respective editions of the Thousand and One Nights (and, in Burton's case, his Supplemental Nights). A different Arabic recension, in which the king is named Naaman and the action takes place in Khurasan, was published in Latin transcription and French translation by M.A. Barthélemy (1887).

The earliest known Persian version, attributed to Shams al-Dīn Muḥammad Daqāyiqī Marvazī, is a particularly impressive piece of literature, and it too has received a fair amount of attention from scholars. It is this version, moreover, which seems to be the source for the widely-traveled recensions and "abridgements" which have been dispersed over an area extending from the Caucasus to the South Pacific. Three manuscript copies of the original work by Daqāyiqi survive, the oldest of which is dated to 663/1265. This version was published by Zabīh Allah Șafã (1345/1966), and it has been translated into Russian by M.-N.O. Osmanov (1977); a Tajik edition was published in 2008 (M. Dilovarov). A second manuscript copy, assessed and partially translated by Nöldeke (1891), dates to $695 / 1296$, and a third is undated but bears the same dedication and largely the same content as the first two (Bruijn, 1993). These latter two copies were the basis of an edition published by Muhammad Rawshan (1349/1970; rpt. 1382/2003), which was translated into Turkish by Abdüsselam and Betül Bilgen (1994).

The first English translation of this text, by Sir William Ouseley, appeared in 1801, and a reprint of this translation was edited and introduced by W.A. Clouston (1883). A French translation by Daniel Lescallier appeared in 1805 and, as Chauvin hints (Chauvin, 16), this version seems quite similar to an English translation published anonymously by Charles Caldwell in 1813 (Caldwell is 
credited on the title-page only as "a citizen of Philadelphia"). A lithograph of another Persian recension was published by Albert de Biberstein-Kazimirski in 1839, though I have been unable to find an extant copy of this item. A more concise prose recension was published, in Persian, by E.E. Bertels (1926), who regarded it as a "popular" (narodnyi) rather than "literary" (literaturnyi) version (Bertels, I). An apparently identical version was published in Iran a few years later (Tabrīzī, 1932), and other "abridged" prose versions were noted by J.A. Decourdemanche (1904) and N.N. Tumanovich (1970).

The "abridged" version published by Bertels (et al) was apparently also the source for a Malay copy which was translated into Russian and discussed by Goriaeva (1989). The Bakhtiyār narrative has indeed been very popular in Malay literature, where it often appears under the title Hikayat Bakhtiar and has been discovered in a number of recensions with varying degrees of proximity to the Persian "abridgement" in terms of content (Braginsky, 2004, 423-431). Less well-known is a verse adaptation in Persian by Fadai (?), apparently published in Iran in 1932, which was translated into Azeri in 2004. Fadai's version was reportedly the basis for at least two translations into Georgian, the earliest of which has been dated to the $18^{\text {th }}$ century (Mämädli, 4-5). ${ }^{2}$

To these we must also add the several texts found in manuscript collections which have yet to be formally studied, as well as the copies I have examined in the Lund University archives. ${ }^{3}$ There are at least two partial copies of the Bakhtiyārnamah in Lund: one copy, dated to 1882, is written in an untrained hand on very coarse Khotan paper (MS Jarring Prov. 74), and the other, undated, is a nearly wordfor-word copy of the former, in more legible script and on more refined paper (which Jarring's handwritten catalog describes as being similar to Khotan paper; MS Jarring Prov. 34). The latter manuscript

\footnotetext{
${ }^{2}$ I have been unable to obtain a copy (or otherwise uncover evidence) of a verse recension published in 1932. Mämädli, translator of the 2004 Azeri text, reports that it was published by Hasan Vahịd Dastgirdī, with Bertels' assistance (Mämädli, 5). Judging from Mämädli's description, this is apparently a different text from the 1932 Tehran publication noted above which, as mentioned, bears a great resemblance to the text published by Bertels in 1927.

${ }^{3}$ Other unstudied Turkic copies have been noted in catalogues: see Hartmann, 6; Muginov, 99-100; Blochet, 623.
} 
has been amended with a title-page and a few brief prefatory lines which declare it to be part of the Jām $\bar{\imath}$ ' al-Hikâyah ("Compendium of Tales"-a generic title). The most substantial differences separating the Lund texts from the many others which have been published or translated are: 1) the addition, in the Lund texts, of a tale which is entirely novel in the context of the Bakhtiyārnamah (see below); and 2) the exclusion of the story of the vizier-turned-rebel and his beautiful daughter, an episode which typically begins the narrative. Instead of the usual beginning, the Lund manuscripts begin with an unnamed enemy from elsewhere (presumably the rebel vizier) attacking the pādishāh's city and forcing him to take refuge with the Shāh of Kirmān.

In all other respects the Lund texts show a high degree of correspondence to the Persian prose version published by Bertels. Because of their unusual origins and context, however, and because of the great interest the narrative and its relatives have aroused among scholars over the last two centuries and the ongoing research related to its global dissemination, I will epitomize the Lund text here in detail.

The tale begins by relating that, in "bygone days" (ötgan zamānda) there was a wealthy and powerful pādishāh named Azādahbakht (sic) who had ten viziers. He was scarcely ever apart from them. One day an army came from another city (bir bulak shahridin) and laid siege to Azādahbakht's kingdom. Azādahbakht fled to the hinterlands along with his pregnant wife, and she gave birth to a son in the wilderness. Unable to take this child with them, they left him in the desert, festooned with jewels. They then rode onward to Kirmān, whose Shāh welcomed them warmly with a lavish party, complete with "jessamine-thighed and fleet-footed cupbearers"

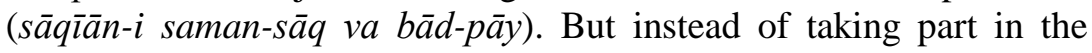
festivities, Azādahbakht wept. The Shāh of Kirmān asked him why he was so unhappy, and Azādahbakht related to him all of the misfortunes which had befallen him. The Shāh urged him to drink wine, reassuring him that his own troops would rectify the matter the very next morning.

When the next morning came the Shāh gathered his troops and marched to Azādahbakht's city. The army which had occupied it fled upon seeing the troops from Kirmān, and Azādahbakht took command of the city once more. Despite his good fortune, he still wept for his child who had been left in the desert, not realizing that the child had 
been in good hands: it had been discovered by a wayfarer who, seeing that the child was decorated with gold and gems, ascertained that it must be a prince. He took the boy in and saw to his education, eventually training him in the arts of combat (sipāhgarchilikk). The boy, named Khudāvār, grew strong and courageous, and he remained always at the side of his adoptive father, whose name was Farrukhzād.

One day Farrukhzād ventured out to plunder a caravan, and he allowed Khudāvār to accompany him. But the assault was not successful, and Khudāvār was taken prisoner and brought before Azādah-bakht. Upon seeing the boy, Azādahbakht had a premonition about him and became quite disconcerted. He asked the boy his name, and the boy replied that his name was Khudāvār and that he would like nothing better than to enter the pādishāh's service in any way possible. Azādahbakht granted this request and re-named the boy Bakhtiyār. He gave Bakhtiyār over to be educated as a scribe (bakhsh $\vec{\imath}$ ), and Azādahbakht came to love him dearly. Bakhtiyār was also charged with caring for the stables, and he excelled so thoroughly in this work that Azādahbakht ordered for him to be trained for the position of treasurer (khazinadārlik ishlari). Bakhtiyār excelled in this position too, and every day the country grew wealthier. Azāhdahbakht grew so close to Bakhtiyār that he used to work out his policies of state in consultation with him. But his ten viziers became jealous of the young man, and they began to speculate about ways to put distance between him and their pādishāh.

One day Bakhtiyār indulged in too much wine. He stumbled into Azādahbakht's harem and fell asleep, with a sword in his hand, right on the pādishāh's throne. Azādahbakht entered the room and, finding the young man in this position, he became enraged. But Bakhtiyār, in his drunkenness, shoved the pādishāh away with his fist and fell back asleep. The exasperated pādishāh ordered that Bakhtiyār be bound and taken away, and then he asked his queen (malīkah) to report on Bakhtiyār's behavior. But the queen insisted that she was utterly unaware of the events that had taken place, and asked that the pādishāh look into the matter further.

Azādahbakht brooded on these events, and he met with his ten viziers the very next day. One of them painted Bakhtiyār's misadventure in sinister terms, citing the boy's dubious pedigree (khün-i nā-haq) and implying that he was undeserving of the favors thus far shown to him. Azādahbakht then ordered that Bakhtiyār be 
brought before him. When Bakhtiyār was brought forth, the pādishāh recounted the favors and affections with which the young man had been received into his care, and he accused Bakhtiyār of plotting his assassination, suggesting that this was the reason he was found on the throne with his sword at the ready. Bakhtiyār pleaded ignorance of the entire episode, explaining that many such things happen to people in their drunkenness ("Ay pādishāh-i 'ālam mast kishilarga shundagh vāq'alar köb boladur").

The chief vizier (katta vazir) then requested permission to seek the queen's recollections of the matter, and the pādishāh assented. The vizier reported to the queen that her husband the pādishāh was ill at ease because of what had come to pass, and that the only acceptable resolution would be that the queen, if questioned further on the matter by Azādahbakht, express her outrage over his having brought Bakhtiyār into their presence and having made him treasurer; further, she must explain that this bastard ( harām-zāda) had entered his harem and threatened both the pādishāh's life and her own. After this, the vizier explained, Azādahbakht would kill the young man.

The queen became enraged, accusing the vizier of deception and slander. She insisted that she had no knowledge of the events in question and asked him why, therefore, she would impugn herself (“nima üchun özümgä özüm tuhmat qiladur?"). The vizier replied that the young man could lawfully be killed because he had once been a thief and had spilled blood. The queen then reluctantly agreed to support the vizier's false version of events, but she warned the vizier that he himself knew of Bakhtiyār's innocence, and that justice would be done on the Day of Judgment (qīyāmat küni).

Delighted, the vizier returned to Azādahbakht and related to him the version of the story to which the queen had just agreed. The pādishāh was outraged and asked that the queen be brought forth. When she was before him, he questioned her and she replied in the manner in which the vizier had instructed her. The enraged Azādahbakht ordered that Bakhtiyār be imprisoned, adding that he would make an example of the young man for all to see. Most of the viziers were delighted, and returned to their homes expecting that the young man would be executed the next morning. But the chief vizier approached the pādishāh yet again and explained that Bakhtiyār's misdeeds should not be made known to the people at large (khalq), nor to other pādishāhs, for fear of what they might say. Thus urged to 
ponder his own humiliation, Azādahbakht ordered that Bakhtiyār be brought before him once again. When Bakhtiyār was present, he told the young man that he was to be executed as an example to all the people of the world.

It is at this point that the Lund manuscripts depart from all other known copies of the Bakhtiyārnāmah. Objecting that he is blameless, Bakhtiyār tells Azādahbakht that his mistake resembles that of the king who, blinded by thirst, struck down the bird of wisdom. His curiosity piqued, the pādishāh asks the young man to relate the episode he has in mind, and here we find interpolated in the manuscript a tale of kingship which is well-known in its own right but which has hitherto had no direct connection to the Bakhtiyārnāmah. The tale in question, with its origins in the Sinbadnämah, can likewise be found in Burton's Arabian Nights, ${ }^{4}$ and it has since enjoyed some popularity in the West, where it has been retold as the tale of "The King and His Hawk" by James Baldwin (1894) and, quite recently, as "Genghis Khan and the Falcon" by the Brazilian novelist Paulo Coelho (2011). ${ }^{5}$ Because the appearance of this brief sequence in the narrative renders the Lund manuscripts unique, I will translate it in full:

In the Chronicles of the Companions it is reported that there was once a pādishāh-grand was he, and great his esteem! One day the pādishāh resolved to go out hunting in the evening. He ordered that [his soldiers] go out with him on a forty day hunt. All of his soldiers accompanied him. They hunted for twenty days, and on the twentyfirst day they mounted their horses for a deer hunt, and they surrounded the deer in the desert. The pādishāh ordered, "Whosoever lets a deer get away, I'll strip him of his rank!" All of the soldiers surrounded and trapped the deer, but suddenly one deer leapt up and

\footnotetext{
${ }^{4}$ A number of scholars over the years have suggested that the Bakhtiyār tale as a whole is a direct "descendent" of the Sinbadnämah, but before now there has been no solid evidence to connect the two works besides their shared structure as "frametales"- a weak connection indeed. The new evidence provided here might strike some as proof of the two tales' shared "ancestry," but I would urge caution here: because the Lund manuscripts were copied only in the nineteenth century, and because they are thus far the only known copies of the Bakhtiyär narrative to contain this tale, we cannot rule out the likelihood that we are observing the relatively recent dovetailing of two tales rather than a "relic" of their common, ancient lineage.

${ }^{5}$ Coelho's version appears to be based on Baldwin's, in which the "King" is likewise identified as Genghis Khan.
} 
escaped before the pādishāh's eyes. With his deer-hawk on his hand, the pādishāh set out after it into the desert.

When he had traveled six farsangs, his mouth was drying up from thirst. But try as he might, he could not catch up with the deer. Thirst drove him half-way up a mountainside, where he saw a drop of rainwater. The pādishāh held out his golden goblet [beneath the rivulet] and in a short time it was filled. He was about to drink the water when the bird on his hand beat its wings. It hit the goblet with its wing and spilled out the water. Three times the pādishāh held out his goblet [to be filled], and three times the bird struck it [and spilled the water out]. The pādishāh cursed and became enraged. He smashed the bird on the ground, where it immediately died.

After that, the pādishāh climbed on foot to the top of the mountain, and he saw a serpent lying stretched out there. A mountain goat seemed likewise to be stretched out resting beside it. The snake had died trying to fit the goat's horns in its mouth. The dripping water, it seems, was the serpent's venom. As soon as the pādishāh realized this he saddened and repented, but it was no use. Finally, he returned to his soldiers. He told them all that had happened. He grieved for the hawk until his dying day. In just this way, if my innocence should be revealed, then repenting after [punishing me] will be no use. ${ }^{6}$

\footnotetext{
6 "Aning hikāyasini itiqāli bashladi Tavārīkh-i așhābida andagh keltürüpdurlar kim bir pādishāh bar érdi 'ażīm ul-shāh wa rafí'al-qadr bir kün pādishāhning khātirigha keldi kim bügün shikārgha chiqay farmān qildi kim qirq künlük shikārgha chiqsünlār be tamām-i lashkar shikārgha bārdilar yigirma kün shikār qildilar yigirma birinchi küni keyik shikāargha ātlandilar ul biyābānda keyiklarni aragha āldilar pādishāh umr qildilar kim keyik kimning bashidin va yā aldidin chiqip zürriyatini qürüturman dedi lashkarlar hammasi keyiklarni qorshap aldilar be-nāgāh bir keyik pādishāhning aldin [sic] chiqip ketgach pädishāhning qolida keyik qushi tütüghliq be taraf-i biyābān ravān boldilar miqdāri alti farsang yerga bardilar tishnalikdin āghzi qürudi anchunān qildilar keyikni alalmay tishnalikdin bir tāgh kamariga chiqip kordilar kim bir qațar su tāmidur pādishāh zarrīn jāmni ul sugha tuttilar āz fursatda toldi khwahladikim suni ichgay darhāal qolidagi qush qanāti birlan urdi su tökaldilar pādishāh uchmarātaba [sic] jāmni tuttilar uchmarātaba qush qanāti birlan urup tökdilar pādishāh nihāyati su sābb erdi dar ghazab bolup qushni yerga urdi darḥāl qush öldi andin keyin pādishāh tāgh üstigha piyāda bolup chiqip kordilar kim bir azhdar öz alip yātidur bir tāgh takkasini damiga tārtqan ekan aning münggüzlari äghzigha sighmasdin azhdar ölüpdur tāmghan su azhdarning zahari ekan müni bilgach pādishāh andagh ghamgin boldilar kim nihāyati kop nadāmatlar qildi faydā [sic] bermadi akhir lashkarigha yānib keldilar ötgan vāqi'ātlarni bir biridin taqrīr qildilar tā ölgüncha ul qushninghasratini yar [sic] erdilar müninggha okhshash mening begunāhliqim ma 'lüm bolsa keyin nadāmat fă 'ida bermas."
} 
As soon as Bakhtiyār finished relating this tale, Azādahbakht ordered that he be taken to prison, where he would wait until dawn while the pādishāh considered his fate. But a second vizier objected, asking that Bakhtiyār's punishment be carried out immediately. Azādahbakht relented, and once again called for Bakhtiyār to be brought before him. He told Bakhtiyār once more that he was to be executed, and Bakhtiyār again pleaded his innocence, adding that in his fickle fortunes he resembled a certain merchant. This piqued the pādishāh's interest, providing a segue for the young man to begin a tale about a wealthy merchant who goes on a journey after losing his wealth. (It should be noted that this tale of the merchant appears in all other known copies of the Bakhtyārnāmah as Bakhtiyār's first "entertainment" for the pādishāh, whereas in this case, as we see, it is his second line of "defense" after the tale of the heroic hawk.)

Bakhtiyār relates that there was a great merchant in the city of Basra who once had much property and land, but whose fortune took a turn for the worse. One year food was in short supply, so the merchant sold whatever he had left in order to stockpile foodstuffs, thinking that food prices would be high by the end of the coming year. But as fate would have it, food prices were low at the end of that year and no one bought a single scrap of his inventory, which began to spoil and reek. The stench offended the people of his neighborhood, who insisted that his rotting stock could not stay there among them. Having nothing left of his goods and property, the merchant packed his few articles of clothing and set off, eventually arriving at the seaside. He boarded a ship, but it was wrecked and sunk by a crosswind, killing nearly all on board. Only the merchant and four others remained, and they floated for ten days before reaching the shore.

The fellow-travelers parted ways, and eventually the merchant arrived at a town. He happened upon a house with a courtyard, and he climbed the gate in order to see if its owner might be amenable to aiding wayfarers and travelers. The owner of the house, a wealthy landholder (dehqān), came out and asked the merchant where he had come from and where he was going. The merchant narrated everything that had happened to him down to the last detail, and was invited into the house. After having a meal together, the dehqan told the merchant that he would give him some farming tools and allow him to keep something of his harvest, and he turned over to the merchant the key to his storehouse. 
The merchant farmed with great enthusiasm. Seeing his gains at harvest time, he buried a portion of the harvest in case the dehqan proved to be unwilling to give it to him. That night, however, unbeknownst to the merchant, thieves made off with the food he had stored away. The next morning, the dehqān gave the merchant his portion of the total harvest, offering him even more than the agreedupon amount out of mercy and compassion. The merchant then told the dehqan that he had buried several sacks of food and offered to turn these over as well. The dehqān sent several people to find the buried food, but they were unable to find it. The dehqān was greatly displeased, and the merchant was sent away in disgrace.

The merchant walked several farsangs and came to the seaside, where he met some pearl-divers (ghavāṣlär). He greeted them and they asked where he came from. The merchant narrated all that had happened to him, and then the pearl-divers consulted with one another and decided that they would swim out into the sea and give to the unfortunate merchant whatever treasures they brought back. Thus they swam out into the sea and each found some pearls. When they returned they gave the merchant such pearls as had never fallen into the hands of any king (bu qism marvārīd hich fädshählar [sic] qoligha tüshgan émas). The merchant took the pearls and went on his way.

As fate would have it, he saw some thieves ahead of him on the road. The merchant considered his predicament and resolved to put three pearls in his mouth and to sew another three into the lining of his coat (tön). When he came upon the thieves, they started chatting with him. As the merchant was talking, however, the pearls suddenly dropped out of his mouth. The thieves grabbed the merchant and beat him. Taking the three pearls, they left. But the remaining pearls were still hidden in his coat. The merchant kept walking until sunset. He finally arrived at a city, where he stopped for the night. The next morning he went looking for the jewelers' market (javāhar-farüsh rastasi). When he found it, he showed off his pearls. The jewelers tied him up, realizing that even the Shāh's own treasury did not have such pearls as those. They discussed the matter with one-another and asked the merchant where he had stolen these pearls, and at this point the Lund manuscript abruptly ends. Despite the fact that the story has clearly been interrupted, the manuscript is concluded with a traditional 
closing formula ("...it is completed with the aid of the king," etc.) as if it had reached its natural completion. ${ }^{7}$

Here, then, we have a novel recension of the widely-traveled Bakhtiyārnamah in two Chaghatay manuscripts from what is now Western China. As mentioned, there are other Eastern Turkic copies of the tale in manuscript collections around the world which have likewise escaped notice, and I hope that the information provided here will offer a basis for further comparisons. The reason these Chaghay copies have remained "hidden in plain sight" for so long may well relate to the nature of our expectations when it comes to the world of Eastern Turkic literature more generally: although a number of the chronicles and other classical works detailing East Turkistan's history were written in Persian, and although there is copious evidence which suggests that - for example - classical Persian and Middle Eastern literature and poetry were widely circulated throughout the region, scholarship on East Turkistani and modern Uyghur culture has tended to focus on purported "ethno-national" traits rather than cosmopolitan valences and global connections. It is my hope, then, that this paper, along with offering a new channel by which to trace the Bakhtiyārnāmah, will also inspire further inquiries into the cosmopolitan heritage of East Turkistani literature.

\footnotetext{
${ }^{7}$ It is possible, then, that the copyist had simply run out of paper! If the merchant's tale were to proceed in the traditional fashion, we would expect that he would then be taken by the jewelers before the king, who, likewise suspecting him of theft, would have him thrown in prison. He would then be saved by the intercession of the pearldivers themselves, who had come to the city in order to observe the prisoners and distribute alms to them. The king would free him, transfer his accuser's wealth to him, and appoint him to the post of treasurer, where he would arouse the jealousy of one of the king's viziers. This vizier would falsely accuse the merchant of conspiring to tunnel into the princess' chambers, and the king would have the merchant blinded and exiled. The king would only later discover the vizier's treachery, at which point it would be too late to make amends for the injustice done to the merchant- thus bringing the Lund manuscripts' novel addition of the tale of the "heroic hawk" directly into dialogue with the tale of the merchant by way of analogy.
} 


\section{References}

Anonymous (Charles Caldwell). Bakhtiar Nameh, or, The Royal Foundling, a Persian Story Exhibiting a Portraiture of Society in the East. Philadelphia: Edward Parker, 1813.

Bakhtiyarnamah. Jarring Collection, Lund University. MS Jarring Prov. 34.

Bakhtiyarnamah. Jarrring Collection, Lund University. MS Jarring Prov. 74.

Baldwin, James. Fifty Famous Stories Retold. New York: American Book Company, 1896.

Barthélemy, M.A. "Histoire de roi naaman, conte arabe dans l'idiome vulgaire de syrie." Journal asiatique 2 (1887): 260-339.

Bertels, E.E. Bakhtiar-name: persidskii tekst i slovar'. Leningrad: Leningradskii institut zhivykh vostochnykh iazykov imeni A.S. Enukidze, 1926.

Biberstein-Kazimirski, Albert de. Bakhtiar-nama: texte persan. Paris: Dondey-Dupre, 1839.

Bilgen, Abdüsselam and Betül. Lüm 'atü's-sirâc li hazreti't-tâc (Bahtıyâr-nâme). Ankara: T.C. Kültür Bakanliği Millī Kütüphane Basimevi, 1994.

Blochet, E. Catalogue des manuscrits turcs, $t$. II. Paris: Bibliothèque nationale, 1932-33.

Braginsky, Vladimir. The Heritage of Traditional Malay Literature: A historical survey of genres, writings and literary views. Leiden: KITLV Press, 2004.

Bruijn, J.T.P. de. "Daqāyeq̄ì Marvaz̄̄, Šams-al-Dīn Moḥammad." Encyclopedia Iranica VI (1993), 660-61.

Burton, Richard Francis. The Book of the Thousand Nights and a Night (Supplemental Nights), 12 vols. Ed. Leonard C. Smithers. London: H.S. Nichols \& Co., 1894-97. 
Chauvin, Victor. Bibliographie des ouvrages arabes ou relatifs aux arabes publies dans l'Europe chretienne de 1800 à 1885, VIII: Syntipas. Liège: Vaillant-Carmanne, 1904.

Chavis, Denis and Jacques Cazotte. Continuation des Mille et une Nuits: contes arabes, vol. 3. Paris: Barde, Manget \& Compagnie, 1789.

Coelho, Paulo. Like a Flowing River: Thoughts and Reflections. New York: HarperCollins, 2011.

Decourdemanche, J.A. "Sur un recension persane inedite de BakhtiarNameh.” Journal Asiatique, 4 (1904), 516-520.

Dilovarov, M. Bakhtiërnoma. Dushanbe: Sarredaksiiai ilmii ensiklopediaii milii tojik, 2008.

Goriaeva, L.V. Povest' o Bakhtiare. Moscow: Nauka, 1989.

Hartmann, Martin. Die osttürkischen Handschriften der Sammlung Hartmann. Berlin: Westasiatische Studien, 1904.

Habicht, Maximilian.Tausend und Eine Nacht, 12 vols. Breslau: J. Max and Co., 1825-43.

Henning, Max. Tausend und Eine Nacht, 24 vols. Leipzig: P. Reclam, 1895-97.

Jaubert, M.A. "Notice et extrait de la Version turque du Bakhtiarnameh, d'après le manuscrit en caractères ouigours que possède la bibliotèque bodléienne d'Oxford." Journal Asiatique, 1 (1827), 146-67.

Knös, Gustavus. Historia decem Vezirorum et filii Regis Azad Bacht, insertis undecim aliis narrationibus. In usum tironum ad codicem manu scriptum Cahirensem. Göttingen: Henrici Dieterich, 1807.

Lescallier, M. Bakhtiar nameh, ou Le favori de la fortune. Paris: J.M. Eberhart, 1805.

Mämädli, Qulom. Baxtiyarnama. Baku: Şärq-Qärb, 2004.

Muginov, A.M. Opisanie uigurskikh rukopisei instituta narodov azii. Moscow: Izdatel'stvo vostochnoi literatury, 1962. 
Nöldeke, Theodor. "Über die Texte des Buches von den zehn Veziren, besonders über eine alte persische Recension desselben," Zeitschrift der Deutschen Morgenländischen Gesellschaft 45 (1891): 97-143.

Osmanov, M.-N.O. Uslada dush, ili Bakhtiiar-name. Moscow: Nauka, 1977.

Ouseley, William, Sir. The Bakhtyar nameh, or, Story of Prince Bakhtyar and the ten viziers: a series of Persian tales. London: Wilson for J. Debrett, 1801.

Payne, John. The Book of the Thousand Nights and One Night. London, "Printed for Subscribers Only" (Cabool edition), 1901.

Rawshan, Muḥammad. Bakhtiyārnāmah: bāznivīsīi Lum 'at al-sirāj li-hazrat al-tāj va Rāhat al-arwāh fì surūr al-mifrāḥ. Tehran, 2003.

Safa, Zabih Allah, Rahat al-arwah fi surur al-mifrah (Bakhtiyarnamah), 2 vols. Tehran: University of Tehran, 1966-69.

Tabrīzī, T. Bakhtiyārnāmah. Tehran, 1932.

Thum, Rian Richard. “The Sacred Routes of Uyghur History.” Diss. Harvard University, 2010.

Tumanovich, N.N. "Neizvestnyi persidskii prozaicheskii variant." Palestinskii sbornik 21/84 (1970): 16-25.

Vámbéry, Hermann [sic]. Uigurische Sprachmonumente und das Kudatku bilik : uigurischer Text mit Transscription und Übersetzung nebst einem uigurisch-deutschen Wörterbuche und lithografirten Facsimile aus dem Originaltexte des Kudatku bilik. Innsbruck: Druck der Wagner'schen UniversitätsBuchdru-ckerei, 1870.

Weil, Gustav. Tausend und Eine Nacht. Ed. August Lewald. Stuttgart: Verlag der Classiker, 1838-41. 
